\title{
Exploration of Child Rearing Practices among Parents of Preschool Aged Children to Develop a Parenting Style Measure in Sri Lanka: A Qualitative Study
}

\author{
Ramya Ekanayake $^{1 *}$, Rasnayaka Mudiyanse ${ }^{1} \&$ V. Pujitha Wickramasinghe ${ }^{2}$ \\ ${ }^{I}$ Department of Paediatrics, Faculty of Medicine, University of Peradeniya, Sri Lanka. ${ }^{2}$ Department of Paediatrics, Faculty of \\ Medicine, University of Colombo, Sri Lanka. Email: ramyaekanayake7@ gmail.com ${ }^{1 *}$
}

Copyright: ( $) 2021$ Ramya Ekanayake et al. This is an open access article distributed under the terms of the Creative Commons Attribution License, which permits unrestricted use, distribution, and reproduction in any medium, provided the original author and source are credited.

The term parenting is used to explain how a child's behavior and development are influenced by parents and its significance on child development, and it has been recognized as early as since 17th century. Developing tools to assess parenting style is a challenge due the influence by socio-economic and cultural factors. Developed instruments taking these facts into consideration would help researchers to assess parenting style. This study aimed to explore the child-rearing practices among Sinhala-speaking parents of preschool-aged children to develop a tool to measure parenting style in Sri Lanka. A qualitative study design was used and guides for focus group discussions and in-depth interviews were developed after a literature survey and further refined with expert opinion in order to cover a broader area of parenting from a local perspective. Two focus group discussions with 6 and 8 purposively selected parents were done; lasted 90-120 minutes. In-depth interviews were conducted with a purposive sample of 10 parents from diverse socio-economic backgrounds, each lasted 45-60 minutes. All the interviews were audio-recorded with permission, transcribed and analyzed by two researchers. After elimination of duplications, 143 codes, 25 subthemes and 5 themes were identified by the thematic analysis. Themes identified were, intentional actions for disciplining children, parental perception in social development of children, parental regulation of activities, parental involvement in pre-school-aged child's education, and parental relationship and responsive care. Results of this study would be useful to develop parenting style assessing questionnaire as well as educationists to develop parenting educational programs in Sri Lanka.

Keywords: Parenting style, Preschool age, Preschool children, Qualitative study, Thematic analysis, Sinhala speaking, Sri Lanka.

\section{Introduction}

Sri Lanka is an island with approximately 22 million population and annual birth cohort of 325,000, claims high standard of health care [1]. Reported neonatal mortality is 4.5 deaths per 1000 live births and maternal mortality is 36.0 for 100000 live births [1]. Parenting style is very much influenced by the culture [2]. Every child born in Sri Lanka is given a Child Health Development Record (CHDR) at birth and it is used to record growth and development [3]. However, there is not much information on parenting style. There is a paucity of literature related to the effect of parental style on child development in Sri Lanka. The term parenting is generally used to explain how a child's behavior and development is influenced by parents [4]. What children learn and how they react in a situation is influenced by their relationships with parents, parenting styles and behaviors [5]. According to research [6],[7], four types of parenting styles exist. They are authoritarian, authoritative, permissive, and neglectful. Parents who are demanding high but not responsive characterize authoritarian style of parenting, also called strict parenting. Authoritative parents take a different, more moderate approach that emphasizes setting high standards, being nurturing and responsive, and showing respect for children as independent, rational beings. Permissive (indulgent) parents usually take on more of a friend's role than a parent's role. Neglectful (uninvolved) parents have an element of being neglectful and expect children to raise by themselves. Children with uninvolved parents struggle with self-esteem issues [8]. Out of these major parenting styles, authoritative parenting is ranked higher in terms of academic achievements, social, emotional and behavioral aptitude of children [9]. Regardless of the fact that parenting styles are indigenously determined, culturally knitted phenomenon, the diversity exist in Western as 
well as in Asian cultures. The cultural context is a mandatory consideration in the development of psychological measures and educational programs of parenting [10]. Also, researchers have followed mixed method; qualitative and quantitative approach to develop parenting assessment tools [10],[11]. Development of an educator program, an understanding of parents' everyday practices, their role in supporting parent-child relationships and children's social and emotional development is important. These findings are critical to the development of an educator-led parent-child relationship program for use within education and care settings [12]. Parents who attend positive parenting training workshops may alter their parenting style and may have positive impact on their children behavioral and cognitive outcomes [13]. In the current study, child rearing practices of preschool aged children were studied and perceived parental expressions were described. As types of expressions may vary according to cultures, lack of literature and gaps in research in Sri Lanka shows the importance of such study. Gaps of the literature include exploration of parenting perceptions, ideas and practices related to child rearing, lack of parenting assessment tools, evaluation of association between parenting and child development in Sri Lankan context.

The thematic analysis is a qualitative data analysis method that can be used as the units of analysis. This process allows researchers to identify and organize relevant themes and subthemes, in subsequent detailed re-readings of the data set, researchers increasingly familiarize themselves with the data and explore the meanings associated with the concepts emerging from participant testimonies [14].

\section{Materials and Methods}

\subsection{The aim, design and setting of the study}

A qualitative design was used, and the study setting was purposively selected parents of preschool aged children in Kandy district to explore child rearing practices among Sinhala speaking parents of preschool-aged children to develop a parenting style measure in Sri Lanka.

\subsection{Focus group discussions and in-depth interviews to generate themes on parenting style in local context}

The guides for focus group discussions (FGDs) and in-depth interviews (IDIs) were developed after a literature survey and expert opinion in order to cover a broader area of parenting styles from a local perspective. IDI guide was modified after conducting FGDs. Permission from the preschool administration and informed written consent from parents were taken prior to data collection. Participants were ensured of their anonymity and they were given the right to withdraw at any stage of the interview.

FGD - Two FGDs with six and eight purposively selected parents were conducted according to a pre-planned guide. The researcher started the FGD after introducing each other and building rapport with the participants. Parents were encouraged to talk about their targets/expectations in bringing up a child, plan or strategy to achieve them, feelings and reactions to success and failures of their child and other interactions with the child. Each FGD lasted for 90 - 120 minutes. Prompts and probes were used during the interview. Confidentiality of the provided information was assured.

IDI - Ten IDIs were conducted based on a pre-planned IDI guide refined after FGDs. A purposive sample of ten parents from diverse socio-economical background was selected. Each interview lasted 45 - 60 minutes. 


\subsection{Themes generation}

All the interviews were audio-recorded with the permission and were transcribed. Qualitative data gathered from both were pooled together for final analysis. Major themes were drawn from the interviews by using thematic analysis. Analysis has been done with two individual researchers to minimize bias. The interviews were analyzed in-depth, and themes were generated by interacting with the data by the first and second researcher.

\section{Results}

\subsection{Descriptive statistics of the study sample}

Tables 1 and 2 show the descriptive characteristics of participants for focus group discussions and in-depth interviews respectively.

Table 1. Descriptive statistics of participants of FGDs

\begin{tabular}{|c|c|c|c|c|}
\hline & No. of participants & Gender & Occupation & No. of children \\
\hline FGD 1 & 06 & Females & $\begin{array}{l}\text { 1. Not employed } \\
\text { 2. Self-employed } \\
\text { 3. Not employed } \\
\text { 4. School van driver } \\
\text { 5. Not employed } \\
\text { 6. Self-employed }\end{array}$ & $\begin{array}{l}03 \\
02 \\
03 \\
03 \\
01 \\
04\end{array}$ \\
\hline FGD 2 & 08 & Females & $\begin{array}{l}\text { 1. Self-employed } \\
\text { 2. Not employed } \\
\text { 3. Not- employed } \\
\text { 4. Teacher } \\
\text { 5. Self-employed } \\
\text { 6. Self-employed } \\
\text { 7. Not employed } \\
\text { 8. Worked in government } \\
\text { sector }\end{array}$ & $\begin{array}{l}03 \\
02 \\
02 \\
03 \\
02 \\
03 \\
02 \\
01\end{array}$ \\
\hline
\end{tabular}

4 and 6 fathers and mothers respectively participated in-depth interviews. Table 2 shows gender, occupation and number of children of participants in in-depth interviews. 
Table 2. Descriptive statistics of 10 participants of in-depth interviews

\begin{tabular}{|c|c|c|c|c|}
\hline $\begin{array}{c}\text { Participant } \\
\text { No. }\end{array}$ & Gender & Age & Occupation & $\begin{array}{c}\text { Number of } \\
\text { children }\end{array}$ \\
\hline Participant 1 & Male & 42 & $\begin{array}{c}\text { Security officer at a government } \\
\text { institute }\end{array}$ & 02 \\
\hline Participant 2 & Female & 41 & Teacher & 02 \\
\hline Participant 3 & Female & 40 & Self-employed & 02 \\
\hline Participant 4 & Female & 46 & Housewife & 03 \\
\hline Participant 5 & Female & 45 & Self-employed & 02 \\
\hline Participant 6 & Female & 37 & Housewife (worked in government & 02 \\
\hline Participant 7 & Female & 33 & Self-employed till recently) & 03 \\
\hline Participant 8 & Male & 28 & Officer in government sector & 03 \\
\hline Participant 9 & Male & 52 & Government development officer & 03 \\
\hline Participant10 & Male & 40 & Staff member of a state university & 03 \\
\hline
\end{tabular}

\subsection{Findings of FGD and IDI data}

All the interviews were audio-recorded with permission and were transcribed. Total number of words spoken was 33,695. Researcher I and researcher II developed 109 codes, 26 subthemes and 6 themes and 221 codes 39 subthemes and 7 themes respectively. After elimination of duplications collectively 143 codes, 25 subthemes and 5 major themes were identified by thematic analysis (Table 3 ).

Table 3. Number subthemes and codes identified under each theme

\begin{tabular}{|c|l|c|c|}
\hline S. No. & Themes & Subthemes & No. of codes \\
\hline 1 & Parental relationship and responsive care & 5 & 25 \\
\hline 2 & Parental perception in social development of children & 5 & 22 \\
\hline 3 & Parental regulation of activities & 5 & 28 \\
\hline 4 & Parental involvement in child's education & 3 & 34 \\
\hline 5 & Intentional actions for disciplining children & 7 & 34 \\
\hline & & $\mathbf{2 5}$ & $\mathbf{1 4 3}$ \\
\hline
\end{tabular}




\subsection{Findings of thematic analysis}

Table 4 shows the results of the thematic analysis: Five (5) major themes and 25 subthemes were recognized after analyzing the qualitative data of FGDs and IDIs.

Table 4. List of themes and subthemes developed

\begin{tabular}{|c|c|}
\hline Themes & Subthemes \\
\hline $\begin{array}{l}\text { 1. Intentional actions for } \\
\text { disciplining children }\end{array}$ & $\begin{array}{l}\text { 1. Appreciation of good behaviors } \\
\text { 2. Verbal hostility } \\
\text { 3. Corporal punishment } \\
\text { 4. Punitive strategies } \\
\text { 5. Reasoning } \\
\text { 6. Parental stress over disciplining the child } \\
\text { 7. Role modelling }\end{array}$ \\
\hline $\begin{array}{l}\text { 2. Parental perception in } \\
\text { social development of } \\
\text { children }\end{array}$ & $\begin{array}{l}\text { 1. Religious education } \\
\text { 2. Culturally regulated customs } \\
\text { 3. Modelling friendships } \\
\text { 4. Social interactions with people } \\
\text { 5. Relationship with siblings }\end{array}$ \\
\hline $\begin{array}{l}\text { 3. Parental regulation of } \\
\text { activities }\end{array}$ & $\begin{array}{l}\text { 1. Time management } \\
\text { 2. Television screening } \\
\text { 3. Setting rules } \\
\text { 4. Decision making } \\
\text { 5. Future expectations }\end{array}$ \\
\hline $\begin{array}{l}\text { 4. Parental involvement in } \\
\text { child's education }\end{array}$ & $\begin{array}{l}\text { 1. Parental responses on child's achievement } \\
\text { 2, Parental responses on child's failures } \\
\text { 3. Parental aid for education }\end{array}$ \\
\hline $\begin{array}{l}\text { 5. Parental relationship and } \\
\text { responsive care }\end{array}$ & $\begin{array}{l}\text { 1. Devote the time } \\
\text { 2. Participation in domestic chores } \\
\text { 3. Parental roles } \\
\text { 4. Physical support in child's needs } \\
\text { 5. Psychological support in child's needs }\end{array}$ \\
\hline
\end{tabular}




\subsection{Elaboration of themes}

Parents' ideas, responses, views, observations and contexts related to these mentioned themes were linked to four parenting styles according to the researcher's perceptions and expert opinion. These data are shown in Tables 5, 6, 7,8 , and 9 . Similar observations have been made by other researchers and published in international literature and are being compared.

\section{Theme 1. Intentional actions for disciplining children}

This theme focuses on parents' view and involvement in disciplining the child. Verbal hostility, corporal punishment, punitive strategies, reasoning, appreciation of good behaviours, stress over disciplining and role modelling emerged as the subthemes (Table 5).

\section{Theme 2. Parental perception in social development of children}

In this study, parental perception in social development was expressed as 5 subthemes; religious education, culturally regulated customs, modeling friendships, social interactions with people and relationship with siblings (Table 6).

\section{Theme 3. Parental regulation of activities}

Parental regulation of activities theme has been evolved with five subthemes; time management, television screening, setting rules, decision making and future expectations (Table 7).

Table 5. Parents' responses related to "Intentional actions for disciplining children" categorized according to four types of parenting styles in comparison with data from selected similar international studies

\begin{tabular}{|c|c|c|c|}
\hline & $\begin{array}{l}\text { Current study (2021), } \\
\text { Parents of preschool } \\
\text { aged children in } \\
\text { Kandy, Sri Lanka }\end{array}$ & $\begin{array}{l}\text { Parents of adolescent children, } \\
\text { Ethiopia [15] }\end{array}$ & $\begin{array}{l}\text { Mexican American parents of } \\
\text { female adolescent children } \\
{[16]}\end{array}$ \\
\hline Authoritative & $\begin{array}{l}\text { "Make child to } \\
\text { understand more } \\
\text { effectively when the } \\
\text { child is disobedient" } \\
\text { (P07). }\end{array}$ & $\begin{array}{l}\text { "As a mother, I should be } \\
\text { patient all the time. Whatever } \\
\text { happens I should be dealing } \\
\text { with it gracefully. I should } \\
\text { patiently advise my children and } \\
\text { when possible I should do what } \\
\text { is needed." }\end{array}$ & $\begin{array}{l}\text { "No brainer. What child will } \\
\text { listen to you or attempt to } \\
\text { change their lives around } \\
\text { when all a parent does is yell } \\
\text { off the top of their lungs? No. I } \\
\text { don't yell. It's pointless. I try } \\
\text { to maintain a respectful } \\
\text { relationship with my } \\
\text { daughter. That's what I } \\
\text { always keep in mind." }\end{array}$ \\
\hline Authoritarian & $\begin{array}{l}\text { "The child should not } \\
\text { be beaten too often... } \\
\text { but should be hit hard } \\
\text { as he can remember his } \\
\text { misbehaviour" (FGD } \\
\text { 02). }\end{array}$ & $\begin{array}{l}\text { "My problem is that they (my } \\
\text { children) don't obey me when I } \\
\text { give them instructions. I used to } \\
\text { beat them a lot but I got } \\
\text { exhausted. I used to hold them } \\
\text { with my teeth. Now I got tired. } \\
\text { They are patient with me. They } \\
\text { don't complain much." }\end{array}$ & $\begin{array}{l}\text { "Well... yeah...we tell her } \\
\text { straight up what she did was } \\
\text { wrong and what she could } \\
\text { have done better. I'm a little } \\
\text { harsh on her only because I } \\
\text { want her to be the best at } \\
\text { everything." }\end{array}$ \\
\hline
\end{tabular}




\begin{tabular}{|c|c|c|c|}
\hline Permissive & $\begin{array}{l}\text { "Children are not } \\
\text { responsible for their } \\
\text { misbehvaiours" (P09). }\end{array}$ & $\begin{array}{l}\text { "I advise and beg them a lot. I } \\
\text { beg them day and night. [I tell } \\
\text { them] Please follow my advice } \\
\text { and study hard. I am very sad } \\
\text { that you don't study hard. As I } \\
\text { care for you, please encourage } \\
\text { me by listening to my advice.' I } \\
\text { don't have rest. I go to } \\
\text { monasteries and pray for them a } \\
\text { lot. With all my endless effort, } \\
\text { they would have turned to be } \\
\text { good. But it didn't happen." }\end{array}$ & \\
\hline Neglectful & $\begin{array}{l}\text { "I do not see any } \\
\text { arguments between my } \\
\text { children due to the } \\
\text { stress caused by them" } \\
\text { (P 06). }\end{array}$ & $\begin{array}{l}\text { "I know that children learn and } \\
\text { improve better through patience } \\
\text { and advise giving. I tell you the } \\
\text { truth, because of the stress in my } \\
\text { life, I couldn't handle my anger. } \\
\text { I regularly yell at them. I'm } \\
\text { often exhausted... They get } \\
\text { sensitive and angry. I get angry } \\
\text { all the time. I complain why they } \\
\text { don't understand my difficulties } \\
\text { and efforts." }\end{array}$ & \\
\hline
\end{tabular}

\section{P-Participant}

Table 6. Parents responses related to "Parental perception in social development of children", categorized according to four types of parenting styles in comparison with data from selected similar international studies

\begin{tabular}{|c|c|c|}
\hline & $\begin{array}{l}\text { Current study (2021), Parents of preschool } \\
\text { aged children in Kandy, Sri Lanka }\end{array}$ & Parents of adolescent children, Ethiopia ${ }^{[15]}$ \\
\hline Authoritative & $\begin{array}{l}\text { "When the child came back from } \\
\text { preschool, I ask ... What happened today... } \\
\text { What did your friends say... Did you play } \\
\text { with your friends ... then he tells all the } \\
\text { details" (P 05). }\end{array}$ & \\
\hline & $\begin{array}{l}\text { "There are some children who scold with } \\
\text { dirty words... so... I instruct my child to } \\
\text { choose a good boy as his friend" (P 07). }\end{array}$ & $\begin{array}{l}\text { "He doesn't spend time with many children. } \\
\text { Particularly he won't make friends with children } \\
\text { we don't approve of." }\end{array}$ \\
\hline Authoritarian & $\begin{array}{l}\text { "We are creating the generations... } \\
\text { Grandfather ... Father ... Mother ... That } \\
\text { way... Descending from them ... They had } \\
\text { a certain methodology... and traits... } \\
\text { which should preserved by young } \\
\text { generation" (P 09). }\end{array}$ & $\begin{array}{l}\text { "IIf] you grow up with this culture for so many } \\
\text { years, you can't change it even if you want to... I } \\
\text { used this culture to raise my children and they } \\
\text { followed up my steps. We connected our ways } \\
\text { with this culture. Our own children and others } \\
\text { that we raised at home follow our ideas and } \\
\text { instructions... I followed up my family's } \\
\text { culture." }\end{array}$ \\
\hline Permissive & $\begin{array}{l}\text { "I know how friends are there now... then } \\
\text { there is no fear associating with them... } \\
\text { they all like same friends."( } \mathrm{P} 04)\end{array}$ & \\
\hline Neglectful & $\begin{array}{l}\text { "Even it is a boy or a girl... it is difficult to } \\
\text { give that social care for a child..." (P 09) }\end{array}$ & \\
\hline
\end{tabular}


Table 7. Parents responses related to "Parental regulation of activities", categorize according to four types of parenting styles in comparison with data from selected similar international studies

\begin{tabular}{|c|c|c|c|c|}
\hline & $\begin{array}{l}\text { Current study (2021), } \\
\text { Parents of preschool } \\
\text { aged children in Kandy, } \\
\text { Sri Lanka }\end{array}$ & $\begin{array}{l}\text { Parents of 5-6 aged } \\
\text { children, Bristol area, UK } \\
\text { [17] }\end{array}$ & $\begin{array}{l}\text { Parents of } \\
\text { adolescent children, } \\
\text { Ethiopia [15] }\end{array}$ & $\begin{array}{l}\text { Parents of preschool } \\
\text { aged children, UK [18] }\end{array}$ \\
\hline & $\begin{array}{l}\text { "It is difficult to get the } \\
\text { child on the right track } \\
\text { by setting rules. I think } \\
\text { children will understand } \\
\text { and act rather than make } \\
\text { children to obey rules" } \\
\text { (FGD } 02 \text { ). }\end{array}$ & $\begin{array}{l}\text { "We keep an eye on it, so } \\
\text { whilst he would wake up } \\
\text { in the mornings and stick } \\
\text { the TV (Television) on, if it } \\
\text { is a school day, no." }\end{array}$ & $\begin{array}{l}\text { "The children are } \\
\text { attracted to what } \\
\text { they see in movies } \\
\text { and TV. They try to } \\
\text { be popular based on } \\
\text { what they see on } \\
\text { media. There are } \\
\text { unhealthy and } \\
\text { uncensored media } \\
\text { influences that lure } \\
\text { them to follow } \\
\text { values that are not } \\
\text { helpful." }\end{array}$ & $\begin{array}{l}\text { "We've got them pass } \\
\text { coded [iPad]. They } \\
\text { can't pick it up without } \\
\text { our permission." } \\
\text { "We tend to do a lot of } \\
\text { iPlayer catch up. So we } \\
\text { know what they're } \\
\text { watching." }\end{array}$ \\
\hline 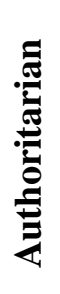 & $\begin{array}{l}\text { "Children should watch } \\
\text { only what their parents } \\
\text { tell them to watch" } \\
\text { (FGD 02). }\end{array}$ & $\begin{array}{l}\text { "I might say 'that's } \\
\text { enough of that Wii (Games } \\
\text { Console), I'm turning it } \\
\text { off, go and find something } \\
\text { that doesn't involve a } \\
\text { screen." }\end{array}$ & & $\begin{array}{l}\text { "No I don't let them } \\
\text { have access, we don't } \\
\text { want them to be having } \\
\text { access all the time } \\
\text { (smartphone), I just } \\
\text { don't like it." }\end{array}$ \\
\hline 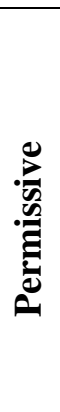 & $\begin{array}{l}\text { "I used the TV to help } \\
\text { when the baby needed to } \\
\text { be fed." (FGD 01). }\end{array}$ & $\begin{array}{l}\text { "We'd like him to become } \\
\text { better at policing it } \\
\text { himself so he, he is quite } \\
\text { good at saying 'I don't } \\
\text { want to watch this } \\
\text { programme, I'll turn it } \\
\text { off'. But yes, if he could, } \\
\text { he'd play on the Wii all } \\
\text { day I think." }\end{array}$ & & $\begin{array}{l}\text { "Yeah they have access } \\
\text { to my iPhone all the } \\
\text { time, when they get hold } \\
\text { of that and I can't find it } \\
\text { anywhere..." }\end{array}$ \\
\hline 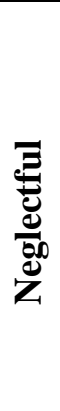 & $\begin{array}{l}\text { "We should not have a } \\
\text { television if we have to } \\
\text { limit their viewing at } \\
\text { home" } \\
\text { (FGD 02). }\end{array}$ & & & $\begin{array}{l}\text { "Oh, we've always got } \\
\text { the TV on, it's pretty } \\
\text { much always on because } \\
\text { when I grew up the TV } \\
\text { was always on, and it's } \\
\text { not a novelty at all... he } \\
\text { won't really sit down } \\
\text { and watch it, it's just } \\
\text { always on." }\end{array}$ \\
\hline
\end{tabular}

\section{P - Participant}

\section{Theme 4. Parental involvement in pre-school aged child's education}

Parental aid for education, responses on child's failures and responses on child's achievements were three subthemes emerged under this theme (Table 8). 


\section{Theme 5. Parental relationship and responsive care}

Devote the time, participation in domestic chores, parental roles, physical and psychological support when the child is in need, have been identified as the five subthemes under this theme (Table 9).

Table 8. Parents' responses related to "Parental involvement in pre-school aged child's education", categorized according to four types of parenting styles in comparison with data from selected similar international studies

\begin{tabular}{|c|c|c|c|c|}
\hline & $\begin{array}{l}\text { Current study (2021), } \\
\text { Parents of preschool aged } \\
\text { children Kandy, Sri } \\
\text { Lanka }\end{array}$ & $\begin{array}{l}\text { Parents of } 1-5 \\
\text { years old children, } \\
\text { Turkey [19] }\end{array}$ & $\begin{array}{l}\text { Parents of adolescent } \\
\text { children, Ethiopia [15] }\end{array}$ & $\begin{array}{l}\text { Mexican American } \\
\text { parents of adolescent } \\
\text { children [16] }\end{array}$ \\
\hline : & $\begin{array}{l}\text { "Tactfully directing the } \\
\text { child to her educational } \\
\text { goals without forcing the } \\
\text { child" (P 01). }\end{array}$ & $\begin{array}{l}\text { "She shall take the } \\
\text { best education, we } \\
\text { must spend good } \\
\text { time with her, } \\
\text { every day we shall } \\
\text { play at regular } \\
\text { hours, every day } \\
\text { she shall learn } \\
\text { something." }\end{array}$ & $\begin{array}{l}\text { "Children should not be } \\
\text { coerced to study. No change } \\
\text { can come with force. You } \\
\text { should come up with another } \\
\text { solution for your fear of what } \\
\text { would happen to the child } \\
\text { who is not studying well." }\end{array}$ & \\
\hline : & $\begin{array}{l}\text { "When the child shows } \\
\text { talent, I give gifts and } \\
\text { make them happy. I } \\
\text { declare that only, if you } \\
\text { do well in education... } \\
\text { you will be rewarded } \\
\text { with gifts" (P 03). }\end{array}$ & & $\begin{array}{l}\text { "There is nothing that makes } \\
\text { me worry as my children not } \\
\text { focusing on their education. I } \\
\text { have no other worries. I tell } \\
\text { them 'I don't want anything } \\
\text { from you. Just learn well. } \\
\text { God knows what will happen } \\
\text { at last." }\end{array}$ & $\begin{array}{l}\text { "All the time. She } \\
\text { knows I want her to } \\
\text { learn and have a } \\
\text { good future. } \\
\text { Everything I say to } \\
\text { her is because I want } \\
\text { her to make better } \\
\text { decisions in life not } \\
\text { like me. I want her } \\
\text { future to be better." }\end{array}$ \\
\hline : & $\begin{array}{l}\text { "I offer gifts whenever } \\
\text { the child asks for gifts" } \\
(\mathrm{P} 08) \text {. }\end{array}$ & & & \\
\hline 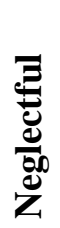 & $\begin{array}{l}\text { "I will not say anything } \\
\text { even if the child is not } \\
\text { properly involved in } \\
\text { education" (FGD 01). }\end{array}$ & & & \\
\hline
\end{tabular}

\section{P-Participant}


Table 9. Parents responses related to "Parental relationship and responsive care", categorize according to four types of parenting styles in comparison of data from selected similar international studies

\begin{tabular}{|c|c|c|c|c|}
\hline & $\begin{array}{l}\text { Current study (2021), } \\
\text { Parents of preschool } \\
\text { children Kandy, Sri } \\
\text { Lanka }\end{array}$ & $\begin{array}{l}\text { Parents of } 1-5 \\
\text { years old } \\
\text { children, } \\
\text { Turkey }{ }^{[19]}\end{array}$ & $\begin{array}{l}\text { Parents of adolescent } \\
\text { children, Ethiopia }{ }^{[15]}\end{array}$ & $\begin{array}{l}\text { Arab immigrant } \\
\text { parents of preschool aged } \\
\text { children }^{[20]}\end{array}$ \\
\hline 苞 & $\begin{array}{l}\text { "We do business in } \\
\text { markets... during } \\
\text { weekdays, I do not attend } \\
\text { on every Thursdays and } \\
\text { Fridays... I stay at home } \\
\text { for those two days... to } \\
\text { monitor the work they } \\
\text { (children) do ... I go } \\
\text { through their work } \\
\text { within those two days ... } \\
\text { Sunday is definitely } \\
\text { reserved for them" (P } \\
\text { 03). }\end{array}$ & & & \\
\hline & $\begin{array}{l}\text { "The child should be } \\
\text { treated with restraint" } \\
\text { (FGD } 02) .\end{array}$ & & & \\
\hline 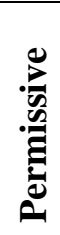 & $\begin{array}{l}\text { "I set aside my time for } \\
\text { the children as they } \\
\text { wanted... I will be with } \\
\text { them when they talk ... } \\
\text { "(P 07). }\end{array}$ & & & \\
\hline$\frac{\Xi}{E}$ & $\begin{array}{l}\text { "No such time has been } \\
\text { set aside to spend with } \\
\text { children... I try to spend } \\
\text { as much time with the } \\
\text { children as possible } \\
\text { because there is less time } \\
\text { to stay with them" } \\
\text { (P 02). }\end{array}$ & $\begin{array}{l}\text { "I am not } \\
\text { sufficient, I } \\
\text { can't play } \\
\text { with him } \\
\text { enough } \\
\text { because of } \\
\text { work, I can } \\
\text { be more } \\
\text { informative } \\
\text { and } \\
\text { instructive } \\
\text { during play." }\end{array}$ & $\begin{array}{l}\text { "We don't have time } \\
\text { to spend with each } \\
\text { other. We are often } \\
\text { busy with work...it's } \\
\text { all about rushing to } \\
\text { get things done both } \\
\text { at work and at } \\
\text { home." }\end{array}$ & $\begin{array}{l}\text { "To be honest, I feel that my } \\
\text { parents are better than me } \\
\text { in raising us. At least in the } \\
\text { past, they had a lot of time } \\
\text { and could communicate } \\
\text { with us easily." }\end{array}$ \\
\hline
\end{tabular}

\section{P- Participant}

\section{Discussions}

This qualitative study generated themes and items for the Parenting Style Assessment Questionnaire-Sinhala (PSAQ-S). Focus group discussions and in-depth interviews revealed five major themes (Table 3). 


\section{Theme 1. Intentional actions for disciplining children}

This theme focuses on parents' view and involvement in disciplining the child. In the current study, participants talked about combined strategies like punishment and reasoning that often helped them to control the behaviors of their preschool aged children.

Verbal hostility, corporal punishment, punitive actions are common authoritarian type of strategies used by parents in our study. These findings are consistent with previous research that have reported, less empathetic authoritarian parents tend to attribute children's misbehaviors to external factors rather than child's internal quality [21]. With refers to Table 5, authoritarian mothers were more likely to respond with greater anger and embarrassment across all child-rearing scenarios. Also, a study [22] in United States of America (USA) showed that African-American parents used more authoritarian strategies with their children than Asian-American parents did. On the other hand, more Asian-American parents seemed to resort to more authoritative parenting strategies to discipline their children.

Parents of current study focus on impulsivity, getting into danger and not obeying parents (Table 5). Tendency for toddlers and preschool aged children to experience physical punishment more than older children has been reported in the United Kingdom (UK) [23]. Also, in North America common use of corporal punishment on toddler and pre-school age children is attributed to child's high activity, exploration and independence, together with negativism, impulsivity and a limited understanding of harm and danger [24].

Appreciation of good behaviors, reasoning and role modelling as the positive parenting strategies were highlighted in our study (Table 5). Explaining/teaching, rewards, diversion, and penalty task and restorative behavior were adopted to discipline daughters whereas corporal punishment, psychological aggression, monitoring, ignoring misbehavior, and deprivation of privileges were used on sons [25]. However, any form of gender-based discrimination in disciplining was not seen in our study.

Believing that the child is not responsible for their misbehaviors was a permissive characteristic noticed in our study and they seem to worry whether child may get hurt/sad upon disciplinary actions. Similar to these findings, in a study in Ethiopia found that parents advise and beg their adolescent child to behave properly [15]. Many parents from USA developed an attribution style which preserved a positive view of their child, describing misbehaviors as situation-specific and outside the child's control [26].

Neglecting type of parental behaviour seen in the study indicated statements like ignoring misbehaviours due to stress cause by the process of disciplining and running out of time to discipline their children. Also, in line with these findings, Kistin et al. (2014) identified themes: repetitive child behaviors are the most stressful, mothers commonly cope by taking time away; this can result in prolonged unsupervised periods for children under 5 years of age in Boston, USA [27].

\section{Theme 2. Parental perception in social development}

This theme reflects parental view and involvement of their child's socialization. The overarching themes that emerged in current study are not so different from themes that have been highlighted in other research on the child 
care settings, such as importance of friends, role of adults and routines [28]. Authoritative parents tend to practice a role of supervising and guiding over child's socialization process. In the current study, it can be seen from the descriptions that parents' awareness of their friends, neighbours and other people around the child. Friendships have an important role in a child's sense of control over their environment, and wider sense of well-being [29].

In the current study, providing education on religion has emerged as an important subtheme (Table 6). Parents expressed that telling religious stories and songs have been fruitful for them to get their child to understand about the society. The influence of religion on child-rearing practices has been very strong in most Asian families. For instance, the Indian views about child nature have been shaped by the sacred Hindu texts of Ramayana, Mahabharata and the Laws of Manu [30].

Authoritarian parenting practices, like forcing the child to associate with selected friends, parents' expectations of must obeying the customs handed down from generation to generation were seen in our study. Wang and Leichtman (2000) also noted that Asian parents ignore personal autonomy as they place a strong emphasis on obedience, dependability, proper behavior, and social commitment [31].

Also, parents express the expectations of their children to obey and respect adults and their advices (Annexure 1). These findings are in line with reported findings as in most Asian cultures, children are always watched not just by their parents, but by the whole community. Shared values and morals make the children know why they need to be good, so they are not bringing shame on their families [32].

Permissive parenting characteristics have allowed their child to engage with friends and people as child wishes. Neglectful parenting is reflected by the expression of even some are not knowing their child's friends. Also, socialization was seen as a daunting task by some parents in our study. However, as Anara et al. (2020) reported, parents are the foundation for shaping the child's perception and ways of interaction with the world, thus contributing to the development of social competences and self-identity in preschoolers [33].

\section{Theme 3. Parental regulation of activities}

In the current study, parents' regulation of activities has evolved with time management, television viewing, setting rules, decision making and future expectations (Table 7). Chao (2002) reported that in Western parenting, dictating to the child what they should do is considered unacceptable and can be perceived as controlling. However, Asian parents often find themselves making choices for their children and being more involved in their lives, think, that more involved they are, the more they love them [34].

Authoritative types of strategies are expressed as making the child to understand and act accordingly rather than obeying rules in our study. The authoritative parent tries to direct the child, but in a rational manner. According to Miller (2010), an authoritative parent's goal is to prepare children to live a fully autonomous life upon adulthood and their children show higher competence, social development, self-perceptions, and positive mental health [35]. Authoritarian parents seem to make rules, implement and monitor them and strictly control their children's behaviour (Table 7). This is keeping in line with the reports by Dwishes (2008) that authoritarian parents, expect their child to always do as they are told by parents without any discussion, keeping in line with parent's rules and 
policy [36]. The current study showed that authoritarian parenting incorporates higher personal expectations regarding the future of the child. Also, Wu and Sen Qi (2005) found that Asian-American parents tend to hold high expectations of their children in their educational attainment but they were not openly passionate with their children. On the other hand, African-American parents were more outgoing with and more expressive to their children but less likely to expect their children to obtain graduate degrees in education [22]. Parents who adopt permissive type of parenting, considered self-regulation to be the right of a child to live freely without outside authority in the current study. Also, Baumrind (1991) has concluded that with this type of parenting, few demands are made of the child regarding such things as chores. This type of parenting does not require the parent to act as an active agent responsible for shaping or altering the child's behavior [6]. Neglectful parents exhibit no regulation at all or no consideration towards child's self-regulation in the current study. Also, parents revealed at times they have led them (children) to view screens when they (parents) wanted to engage in some of their personal work. In a study conducted in Southeastern part of America, also reported that parents of children aged 3-5 years used screens as a way to distract their child, so that they are able to attend to their personal tasks, or even to take a break[37] and similar responses have been expressed in our study as well.

\section{Theme 4. Parental involvement in preschool aged children's education}

This theme involved parental responses on children's achievements, parents' responses on children's failures and aid for education. The mothers of preschool aged children are also concern in the educational performance of their children. Current study showed tactfully directing and more engaging attitude without forcing the child towards education as an important aspect of authoritative parenting characteristics. Similar responses were seen in studies conducted in Turkey and Ethiopia; spending better times for child's learning [19] and come up with better solutions without coerce and forcing [15]. The current study showed that authoritarian parenting strategies included, forcing the child towards education, appreciating and offering gifts were done only if the child showed achievements. It seems, this may have aggravated by the competitive world around the child. Some parents in our study believed that to be a good parent, they should be more educated and more knowledgeable. Faircloth and Murray (2014) also reported that feeling the pressure and guilt of not doing their best, because they are being surrounded by a new parenting culture [38].

Permissive characteristics of parents in the current study was expressed through offering gifts whenever child want in an irrational manner and allowing child to engage in learning activities as they wish. It seems, the reason for expressing these characteristics are related to the fact that parents think the child is in preschool age and should not force on education. Neglectful parenting is expressed through no consideration on children even if they do not perform well in their study activities.

\section{Theme 5. Parental relationship and responsive care}

Parental relationship and responsive care have emerged as a theme in the current study. Devoting time for their child has varied among parents and seems it has affected by the parents' occupation in the current study. Authoritative parents tend to have more interactive time with their child and parents' commitment is admirable on relationship with their child and support given in the current study. However, care is limited to noticing, 
understanding, providing feedback and support rather than real engagement in responsive care. Anne (2012) reported, a substantial part of the caregivers also was concerned about the need to spend sufficient time together with the young children to be able to establish and maintain positive relationships [39].

In our study, authoritarian parents act more as a ruler and believed that child should be treated with restraint and parents can't be friendly with the child (Table 9). Previous research reported that, Asian children are quieter, submissive and follow orders, less talkative and vocally less active than Euro-American children due to maintaining control over them. Asian children are brought up in such a way that they do not openly express their opinions on certain issues [32].

Permissive parenting characteristics showed through allowing children to spend time as the child wants, playing a more of a friends' role, trying to fulfill all the physiological and psychological needs of children as the child wants. Research showed, Asian mothers are inclined towards a total indulgence of their child's wishes and demands, whether these are related to feeding, cleaning, sleeping or keeping company [40]. Neglectful parenting characteristics showed through the expression of lack of time to spend with children or due to stress cause by workload. However, there were parents who exhibit authoritative parenting characteristics even though they work. Therefore, it seems it's a matter of planning their time to spend with their children.

\section{Conclusions}

Cultural context should emphasize as much as that is required in the development of measures of parenting for a particular culture. The subthemes present a thematic basis for the development of a quantitative instrument to identify the parenting style with regards to the four parenting styles. Impact of parenting style on child's holistic, cognitive, psychosocial and emotional development should be evaluated in a national level study in Sri Lanka. Innovative methods of inculcating healthy parenting should be explored and success of such interventions could be assessed by validated tools as an ongoing process in the country.

\section{Declarations}

\section{Source of Funding}

This research is funded by University Research Grants, University of Peradeniya (URG/2019/20/M).

\section{Competing Interests Statement}

The authors declare no competing financial, professional and personal interests.

\section{Consent for publication}

Authors declare that they consented for the publication of this research work.

\section{Author contributions}

Ramya Ekanayake - conceived and designed the analysis, collected and analyzed data and prepared final manuscript; writing - review and editing. Prof. Rasnayaka Mudiyanse - conceived and designed the analysis, and prepared final manuscript; writing - review and editing. Prof. V. Pujitha Wickramasinghe - conceived and design the analysis, prepared final manuscript; writing - review and editing. 
Asian Journal of Basic Science \& Research

Volume 3, Issue 4, Pages 83-99, October-December 2021

References

[1] World Health Organization (2020). Sexual, reproductive, maternal, newborn, child and adolescent health policy survey, 2018-2019. https://www.who.int/data/maternal-newborn-child-adolescent/static-visualizations/adolesce nt-country-profile.

[2] Bornstein M.H. (2012). Cultural Approaches to Parenting. Parenting, science and practice. Vol.12, Iss.2-3, Pages 212-221.

[3] Ministry of Health (2007). Child Health Development Record. Family Health Bureau.

[4] Bornstein M.H. (2002). Parenting infants. In M. H. Bornstein (Ed.), Handbook of parenting: Children and parenting, 1(2), Pages 3-43.

[5] Collins W.A. \& Laursen B. (1999). The Minnesota symposia on child psychology: Relationships as developmental contexts.

[6] Baumrind, D. (1971). Current patterns of parental authority. Dev Psychol Monogr. 4(1).

[7] Maccoby, E. \& Martin, J. (1983). Socialization in the context of the family: Parent-child interaction. In: Mussen PH, editor. Handbook of Child Psychology. Wiley; New York: 1-101.

[8] Sanvictores, T. \& Mendez, M.D. (2021). Types of Parenting Styles and Effects on Children. StatPearls Publishing.

[9] Times of India (2021). Psychologists share Authoritative parenting style is the best! Here's why.

https://timesofindia.indiatimes.com/life-style/parenting/moments/psychologists-share-authoritative-parenting-styl e-is-the-best-heres-why/articleshow/86939305.cms

[10] Syeda S.B. \& Mumtaz A. (2015). Development and Validation of Parenting Style Scale. Pakistan Journal of Psychological Research, 30 (2), Pages 225-248.

[11] Sleddens et al.: Development of the Comprehensive General Parenting Questionnaire for caregivers of 5-13 year olds. International Journal of Behavioral Nutrition and Physical Activity 2014, 11:15.

[12] O’Connor A., Nolan A., Bergmeier H., Williams-Smith, J. \& Skouteris (2018). Early Childhood Educators' Perceptions of Parent-child Relationships: A Qualitative Study. Australasian J. of Early Childhood. 43(1): 4-15.

[13] Paul C. (2021). Effectiveness of Positive Discipline Parenting Program on Parenting Style, and Child Adaptive Behavior, Child Psychiatry \& Human Development. Available at https://doi.org/10.1007/s10578- 021-01201-x.

[14] Oscar L., Castro C., Wright, R. \& Chamblas, I. (2019). Thematic Analysis in Social Work: A Case Study, “Global Social Work-Cutting Edge Issues and Critical Reflections, Bala Raju Nikku, IntechOpen”, doi: 10.5772/intechopen.89464.

[15] Gelan B.W. (2016). A qualitative exploration of values and experiences of parents raising adolescent children in Addis Ababa, Ethiopia (Thesis). PhD (Doctor of Philosophy): University of Iowa. 
[16] Morad, S.G. (2014). A qualitative study determining the parenting styles and strategies most commonly utilized by Mexican American parents in fostering leadership traits in female adolescents. Doctor of Education, Pepperdine University. Available at: https://digitalcommons.pepperdine.edu/cgi/viewcontent.cgi?article=1501 \&context=etd1.

[17] Jago R., Zahra J., Edwards M.J., Kesten J.M., Solomon M.E., Thompson J.L. \& Sebire, S.J. (2016). Managing the screen-viewing behaviours of children aged 5-6 years: a qualitative analysis of parental strategies, BMJ Open. 6:e010355.

[18] Bentley, G.F., Turner K.M. \& Jago, R. (2016). Mothers' views of their preschool child's screen-viewing behaviour: A qualitative study. BMC Public Health, 16(718).

[19] Zeynep T.B. (2015). Procedia - Social and Behavioral Sciences, 197, Pages 2417-2424.

[20] Majedh F.A.A.R. (2013). Parenting styles used with preschool children among Arab immigrant parents in a U.S. context. Doctor of Philosophy, Colorado State University Fort Collins, Colorado.

[21] Coplan, R.J., Hastings, P.D., Lagace-Seguin D. \& Moulton C.E. (2002). Authoritative and authoritarian mothers' parenting goals, attributions and emotions across different child-rearing contexts. Parenting: Science \& Practice, 2(1), Pages 1-26.

[22] Wu F. \& Sen Qi. (2005). Parenting within Cultural Context: Comparisons between African-American and Asian-American Parents. Annual conference of American Educational Research Association, Montreal, Canada.

[23] Ghate, D., Hazel, N., Creighton, S., Finch, S. \& Field, J. (2003). The National Study of Parents, Children and Discipline in Britain. London: Policy Research Bureau.

[24] Clément, M.E., Bouchard, C., Jetté, M. \& Laferrière, S. (2000). Family violence in the lives of children in Quebec, 1999. Quebec: Institute of Statistics of Quebec.

[25] Clara, P.K., Fitri, A.A., Eka R.P. \& Langgersari E. (2016). How Are Parents Disciplining Their Preschool Children. Advances in Social Science, Education and Humanities Research (ASSEHR), 58.

[26] Dix, T.H. \& Grusec, J.E. (1985). Parental attribution processes in child socialization. Sigel I.E. Ed. Parental belief systems: Their psychological consequences for children. Hillsdale, NJ: Lawrence Erlbaum, Pages 201-233.

[27] Kistin, J. C., Radesky, J., Diaz-Linhart, Y., Martha, C.T., O’Connor, E., Silverstein M. (2014). A Qualitative Study of Parenting Stress, Coping, and Discipline Approaches among Low-Income Traumatized Mothers. Journal of Developmental \& Behavioral Pediatrics, 35(3), Pages 189-196.

[28] Clarke-Steward A. \& Allhusen V. (2005). What we know about childcare. Cambridge, MA and London: Harvard University Press.

[29] Rubin, K.H., Bukowski W.M. \& Parker J.G. (2006). Peer interactions, relationships and groups. In: Eisenberg, N, Damon, W, Lerner, RM. eds. Handbook of Child Psychology: Social, Emotional and Personality Development, Hoboken, NJ: Wiley, 3, Pages 571-645. 
[30] Patel N.V. (1999). Childrearing in Hindu Gujarati Indian families in America: Effects of modernity and acculturation. Master of Arts, Department of Psychology, University of Houston.

[31] Wang, W. \& Leichtman, M.D. (2000). Same beginnings, different stories: A comparison of American and Chinese children's narratives. Child Development, 71, Pages 1329-1346.

[32] Zhao X. (2002). Remaking Chinese America: immigration, family, and community, 1940-1965. New Jersey: Rutgers University Press.

[33] Anara, D., Aliya, B., Amangeldu, Z., Gulmira Z. \& Gulimzhan, T. (2020). The process of socialization of the child's personality in the conditions of interaction of family and preschool educational institution. Journal of Critical Reviews, 20(7).

[34] Chao R.K. \& Tseng, V. (2002). Parenting of Asians. Bornstein M.H. Ed. Handbook of Parenting, 1, 59-93. [35] Miller M.J. (2010). Social Learning and Imitation. New Haven, CT: Yale University Press.

[36] Dwishes (2008). Parenting style. The Preschool Years. Study Mode.com. Available at: http://www. studymode.com/essays/parentingstyles-preschool-years-136868.html

[37] Joseph, E.D., Kracht, C.L., Romain J., Allen, A.T., Barbaree, C., Martin C.K. \& Staiano A.E. (2019). Young Children's screen time and physical activity: perspectives of parents and early care and education center providers. Global Pediatric Health, 6.

[38] Faircloth C. \& Murray, M. (2014). Parenting: kinship, expertise and anxiety. Journal of Family Issues, 1-15.

[39] Anne, M.U. (2012). Relationships between young children in full-time day care and their caregivers: A qualitative study of parental and caregiver perspectives. Early Child Development and Care, 182 (9): 1155-1165. [40] Roopnarine J.L. \& Carter B. (1992). Parent-child socialization in diverse cultures. Eds. Norwood, NJ: Ablex. 